\title{
PREVALENSI HIPERTENSI PADA PENDUDUK UMUR 30 TAHUN HINGGA 80 TAHUN DI DESA MENANGA RENDANG KARANGASEM BALI TAHUN 2012
}

\author{
Dewa Ayu A. Diah Hadiningrat ${ }^{1}$ \\ ${ }^{1}$ Program Studi Pendidikan Dokter, Fakultas Kedokteran Universitas Udayana \\ (diahhadiningrat@yahoo.com)
}

\begin{abstract}
ABSTRAK
Latar Belakang: Di wilayah kerja Puskesmas Rendang menunjukkan kasus hipertensi menduduki peringkat kesembilan dengan jumlah kasus sebesar 950 (3.50\%) di mana sebagian besar kasus terjadi pada kelompok umur 30 tahun hingga 80 tahun. Kematian akibat stroke pada tahun 2011 menduduki tempat ketiga dengan total 11 kematian (5.79\%). Gaya hidup masyarakat merupakan salah satu faktor resiko untuk terjadinya hipertensi.

Metode Penelitian: Rancangan penelitian dengan menggunakan pendekatan deskriptif kuantitatif. Populasi adalah seluruh penduduk kelompok umur 30 tahun hingga 80 tahun di Dusun Menanga Kangin, Desa Menanga, Kecamatan Rendang, Kabupaten Karangasem pada bulan Juni 2012 yang berjumlah 961 orang (39 sampel).

Hasil Penelitian: Mayoritas responden yang menderita hipertensi berumur di atas 60 tahun (53.8\%). Dari 39 sampel, 13 responden menderita hipertensi, 76.9\% mengkonsumsi buah-buahan dalam kategori tidak cukup, $100 \%$ mengkonsumsi sayuran dalam kategori tidak cukup, $97.4 \%$ mengkonsumsi daging dengan $44.7 \%$ mengkonsumsi jenis daging merah, 33.3\% merokok, 10.2\% mengkonsumsi minuman beralkohol, dan 53.8\% tidak melakukan aktivitas fisik. Hasil uji statistik Chi square menunjukkan bahwa hasil penelitian tidak dapat digeneralisasi ke populasi dan hanya berlaku pada sampel.

Kesimpulan:Kejadian hipertensi pada responden yang mengkonsumsi buah dalam kategori tidak cukup (34.5\%), pada yang mengkonsumsi sayur dalam kategori tidak cukup (39.4\%), pada yang mengkonsumsi daging (31.6\%), pada responden yang merokok (15.4\%), pada responden yang mengkonsumsi minuman beralkohol (25.0\%), dan pada responden yang tidak melakukan aktivitas fisik (42.9\%). Hasil penelitian menunjukkan adanya kecenderungan peningkatan tekanan darah terhadap gaya hidup.
\end{abstract}

Kata kunci: Prevalensi, hipertensi, penduduk, gaya hidup

\section{ABSTRACT}

Background: Hypertension cases at coverage of work of Puskesmas Rendang is ranked number 9of 10 major diseases whereby majority of the cases are among people at the age of 30 y.o. to 80 y.o. with the total number of 950 cases(3.50\%). Death due to stroke in year 2011 is ranked number 3 with the total number of 11 deaths (5.79\%). Lifestyle of the community is one of the factor of hypertension.

Method: This research uses quantitative descriptive. Population for this study is the whole community of Desa Menanga, Kecamatan Rendang, Kabupaten Karangasem within the age of 30 y.o. to 80 y.o.on June with the total of 961 people ( 39 sampels).

Results: Majority of the respondents who suffer from hypertension are above the age of 60 y.o. (53.8\%). From the total of 39 sampels, 13 respondents suffer from hypertension, $76.9 \%$ consume inadequate amount of fruits, $100 \%$ consume inadequate amount of vegetables, $97.4 \%$ consumes meat from where $44.7 \%$ consume red meat, $33.3 \%$ smoke cigarette, $10.2 \%$ consume alcoholic drinks and $53.8 \%$ do not perform physical activities. Conclusion: Hypertension is found on respondents who consume inadequate amount of fruits (34.5\%), respondents who consume inadequate amount of vegetables $(39.4 \%)$, respondents who consume meat (31.6\%), respondents who smoke cigarette $(15.4 \%)$, respondents who consume alcoholic drinks $(25.0 \%)$ and respondents who do not perform physical activities (42.9\%). The result of this research shows there is a tendancy of hypertension based on lifestyle.

Keyword: Prevalence, hypertension, community, lifestyle 


\section{PENDAHULUAN}

Hipertensi adalah tekanan sistolik $\geq 140 \mathrm{mmHg}$ dan tekanan diastolik $\geq 90 \mathrm{mmHg}$ secara kronik. Hipertensi sering dijumpai pada individu diabetes mellitus (DM) dimana diperkirakan prevalensinya mencapai 50-70\%. Sampai saat ini hipertensi masih tetap menjadi masalah karena beberapa hal, antara lain meningkatnya prevalensi hipertensi, masih banyaknya pasien hipertensi yang belum mendapatkan pengobatan maupun yang sudah diobati tetapi tekanan darahnya belum mencapai target, serta adanya penyakit penyerta dan komplikasi yang dapat meningkatkan morbiditas dan mortalitas. ${ }^{1}$

Prevalensi kejadian hipertensi dilaporkan berbeda di seluruh dunia dengan prevalensi terendah di daerah pedalaman India (3,4\% pada laki-laki dan 6,8\% pada wanita) dan tertinggi di Poland (68,9\% pada lakilaki dan $72,5 \%$ pada wanita). Kesadaran penderita bahwa mereka menderita hipertensi adalah sekitar $46 \%$ dan mengalami perbedaan dari $25,2 \%$ di Korea hingga 75\% di Barbados. Sebanyak 10,7\% penderita hipertensi menjalani pengobatan untuk hipertensi sementara di Bardados angkanya mencapai 66\%. Penyakit hipertensi dalam keadaan terkontrol ( tekanan darah < 140/90 sewaktu masih meminum obat antihipertensi) sejumlah $5,4 \%$ di Korea sementara di Barbados sejumlah 58\%. Kesimpulan dari penelitian tersebut adalah hipertensi merupakan masalah besar di dunia terutamanya di negara berkembang. ${ }^{2}$

Angka-angka prevalensi hipertensi di Indonesia telah banyak dikumpulkan dan menunjukkan di daerah pedesaan masih banyak penderita yang belum terjangkau oleh pelayanan kesehatan. Di Indonesia, banyaknya penderita hipertensi diperkirakan 15 juta orang tetapi hanya $4 \%$ yang merupakan hipertensi terkontrol. Prevalensi 6-15\% pada orang dewasa, 50\% diantaranya tidak menyadari sebagai penderita hipertensi sehingga mereka cenderung untuk menjadi hipertensi berat karena tidak menghindari dan tidak mengetahui faktor risikonya, dan 90\% merupakan hipertensi esensial. Saat ini penyakit degeneratif dan kardiovaskuler sudah merupakan salah satu masalah kesehatan masyarakat di Indonesia. ${ }^{3}$ Sedangkan prevalensi hipertensi di Bali berdasarkan diagnosis tenaga kesehatan dan atau minum obat hipertensi berkisar antara 3,4\%-8,4\%. ${ }^{4}$

Penyakit hipertensi dapat mengakibatkan gejala yang berlanjut untuk suatu target organ, seperti strok untuk otak, penyakit jantung koroner untuk pembuluh darah jantung dan otot jantung. Pada akhir abad ke-20, penyakit jantung dan pembuluh darah menjadi penyebab utama kematian di negara maju dan negara sedang berkembang. Berdasarkan Survei Kesehatan Rumah Tangga (SKRT) tahun 2001, kematian akibat penyakit jantung dan pembuluh darah di Indonesia sebesar 26,3\%. Sedangkan data kematian di rumah sakit tahun 2005 sebesar 16,7\%. ${ }^{5}$ Dalam studi yang dijalankan di Medical 'B' unit Ayub Teaching Hospital, Abottabad dari Nopember 2003 hingga Januari 2005, hipertensi dikatakan faktor resiko paling sering untuk kejadian strok. Dari 91 kasus, 51 (56,04\%) menderita hipertensi. Tiga puluh lima pasien adalah laki-laki dan enam belas pasien perempuan. Strok dikatakan cenderung menyerang penderita hipertensi pada sekitar umur 6170 tahun bagi laki-laki dan 51-60 tahun bagi penderita perempuan. $^{6}$

Diperkirakan sekitar $80 \%$ peningkatan kasus hipertensi terutama di negara berkembang tahun 2025 dari sejumlah 639 juta kasus di tahun 2000, di perkirakan menjadi 1,15 milyar kasus di tahun 2025. Prediksi ini didasarkan pada angka penderita hipertensi dan pertambahan penduduk saat ini. ${ }^{3}$ Modifikasi gaya hidup sangat penting dalam mencegah tekanan darah tinggi dan merupakan bagian yang tidak dapat dipisahkan dalam mengobati tekanan darah tinggi.

Puskesmas Rendang merupakan Puskesmas induk yang terdapat di Kecamatan Rendang, Kabupaten Karangasem. Menurut data yang diperoleh dari Perencanaan Tingkat Puskesmas 2012 (PTP), Jumlah penduduk Kecamatan Rendang berdasarkan hasil proyeksi penduduk tahun 2011 berjumlah 35.847 jiwa. Menurut data Puskesmas Rendang, kasus hipertensi di Wilayah Kerja Puskesmas Rendang pada tahun 2011 menduduki peringkat ke- 9 dalam 10 kasus tertinggi dengan jumlah 950 kasus (3.50\%).

Menurut data Perencanaan Tingkat Puskesmas tahun 2012, kematian akibat stroke pada wilayah kerja Puskesmas Rendang Tahun 2011 menduduki tempat ketiga dengan total 11 kematian (5.79\%). Berdasarkan data sekunder yang diperoleh dari Register Puskesmas Rendang dari Januari 2012-Mei 2012, dari 248 kasus hipertensi, 229 kasus berasal dari kelompok 30 tahun 80 tahun dengan laki-laki berjumlah 79 kasus dan perempuan berjumlah 150 kasus. Kasus hipertensi terbanyak ditemukan di Desa Menanga dengan 126 kasus. Dari 126 kasus tersebut, mayoritas penderita hipertensi berasal dari Dusun Menanga Kangin, Desa Menanga, Kecamatan Rendang, Kabupaten Karangasem dengan total penderita 75 orang di mana Dusun Menanga Kangin merupakan dusun yang paling dekat dengan Puskesmas Rendang. Ada banyak faktor risiko hipertensi, beberapa di antaranya dapat dikendalikan dan dikontrol. Umur, jenis kelamin dan genetik merupakan faktor resiko yang tidak dapat dikontrol. Sementara obesitas, kurang olahraga, merokok, dan stress emosional merupakan faktor resiko yang dapat dikontrol. ${ }^{7,8}$

Gaya hidup adalah perilaku seseorang yang ditunjukkan dalam aktivitas, minat dan opini khususnya yang berkaitan dengan citra diri untuk merefleksikan 
status sosialnya. Pada beberapa penelitian mengenai faktor risiko hipertensi di berbagai negara menunjukkan hasil yang signifikan antara pengaruh gaya hidup yaitu makanan, merokok, minum minuman beralkohol, dan kurang melakukan aktivitas fisik. ${ }^{7,8}$ Latar belakang tersebut yang mendasari kami untuk menjalankan survey prevalensi hipertensi berdasarkan gaya hidup pada penduduk kelompok umur 30 tahun hingga 80 tahun di Dusun Menanga Kangin, Desa Menanga, Kecamatan Rendang, Kabupaten Karangasem pada bulan Juni 2012 .

\section{METODE}

Penelitian ini merupakan penelitian deskriptif kuantitatif untuk mengetahui prevalensi hipertensi berdasarkan gaya hidup pada penduduk kelompok umur 30 tahun hingga 80 tahun di Desa Menanga, Kecamatan Rendang, Kabupaten Karangasem pada bulan Juni 2012.
Populasi dalam penelitian ini adalah seluruh penduduk kelompok umur 30 tahun hingga 80 tahun di Dusun Menanga Kangin, Desa Menanga, Kecamatan Rendang, Kabupaten Karangasem pada bulan Juni 2012.

Sampel dalam penelitian ini berjumlah 39 orang yang merupakan penduduk kelompok umur 30 tahun hingga 80 tahundi Dusun Menanga Kangin, Desa Menanga, Kecamatan Rendang, Kabupaten Karangasem pada bulan Juni 2012yang memenuhi kriteria inklusi penelitian.Sampel dipilih dengan metode simple random sampling. Adapun variabel yang akan diteliti adalah gaya hidup. Dalam penelitian, gaya hidup yang dimaksud adalah pola makan, kebiasaan merokok, kebiasaan mengkonsumsi alkohol serta aktivitas fisik yang dilakukan.

Analisis data dilakukan secara deskriptif. Penyajian data berupa tabulasi dari kuesioner survei dan dijabarkan menggunakan tabel kemudian dijelaskan secara naratif.

Tabel.1Karakteristik Responden

\begin{tabular}{|c|c|c|c|}
\hline No & Karakteristik & Frekuensi & Persentase (\%) \\
\hline \multirow[t]{4}{*}{1} & Kelompok umur(tahun) & & \\
\hline & - $\quad<45$ & 16 & 41.0 \\
\hline & - $\quad 45-60$ & 15 & 38.5 \\
\hline & - $>60$ & 8 & 20.5 \\
\hline \multirow[t]{3}{*}{2} & Jenis Kelamin & & \\
\hline & - Laki-laki & 26 & 66.7 \\
\hline & - Perempuan & 13 & 33.3 \\
\hline \multirow[t]{4}{*}{3} & Tekanan darah & & \\
\hline & - Normal & 18 & 46.2 \\
\hline & - $\quad$ Pre-hipertensi & 8 & 20.5 \\
\hline & - Hipertensi & 13 & 33.3 \\
\hline \multirow[t]{3}{*}{4} & Konsumsi buah & & \\
\hline & - $Y a$ & 30 & 76.9 \\
\hline & - $\quad$ Tidak & 9 & 23.1 \\
\hline \multirow[t]{3}{*}{5} & Konsumsi sayur & & \\
\hline & - Ya & 39 & 100 \\
\hline & - $\quad$ Tidak & 0 & 0 \\
\hline \multirow[t]{3}{*}{6} & Konsumsi Daging & & \\
\hline & - $Y a$ & 38 & 97.4 \\
\hline & - Tidak & 1 & 2.6 \\
\hline \multirow[t]{3}{*}{7} & Merokok & & \\
\hline & - $\quad Y a$ & 13 & 33.3 \\
\hline & - Tidak & 26 & 66.7 \\
\hline \multirow[t]{3}{*}{8} & Konsumsi minuman beralkohol & & \\
\hline & - $Y a$ & 4 & 10.3 \\
\hline & - Tidak & 35 & 89.7 \\
\hline \multirow[t]{3}{*}{9} & Aktivitas fisik & & \\
\hline & - $Y a$ & 18 & 46.2 \\
\hline & - Tidak & 21 & 53.8 \\
\hline Total & & 39 & 100,0 \\
\hline
\end{tabular}


HASIL

Karakteristik Responden

Penelitian dilakukan terhadap 39sampel dari 961 penduduk, yang menjadi responden adalah penduduk kelompok umur 30 tahun hingga 80 tahun yang dipilih secara random dan bertempat tinggal di Dusun Menanga Kangin, Desa Menanga, Kecamatan Rendang, Kabupaten Karangasem. Dari sejumlah responden yang terpilih secara random untuk menjadi sampel, seluruhnya menyatakan bersedia untuk ikut serta di dalam penelitian ini.

Pengumpulan data dilaksanakan pada tanggal 1 Juli 2012. Wawancara dilakukan oleh dua orang mahasiswa dan dilakukan dengan mengunjungi rumah responden. Dari 39 responden yang telah diwawancarai, diperoleh karakteristik penduduk meliputi usia, jenis kelamin, tekanan darah, konsumsi buah, konsumsi sayuran, konsumsi daging, merokok, konsumsi minuman beralkohol, dan aktivitas fisik.

Dari data yang diperoleh, mayoritas responden berada dalam kelompok umur kurang dari 45 tahun (41.0\%). Sebagian besar responden merupakan laki-laki (66.7\%). Dari 39 responden, 33.3\% mengalami hipertensi. Sebanyak $76.9 \%$ responden mengkonsumsi buah, $\quad 100 \%$ mengkonsumsi sayuran, $97.4 \%$ mengkonsumsi daging, 33.3\% merokok, $10.3 \%$ mengkonsumsi minuman beralkohol, dan $46.2 \%$ responden melakukan aktivitas fisik.

Proporsi Hipertensi Berdasarkan Jenis Kelamin

Dari data yang diperoleh (tabel 2), didapatkan dari 39 responden $33.3 \%$ menderita hipertensi di mana kebanyakan penderita hipertensi adalah laki-laki sebesar $69.2 \%$, sedangkan perempuan sebesar $30.8 \%$.

Tabel.2 Kejadian hipertensi berdasarkan jenis kelamin

\begin{tabular}{|c|c|c|c|c|}
\hline \multirow{2}{*}{$\begin{array}{l}\text { Jenis kelamin } \\
\text { responden }\end{array}$} & \multicolumn{3}{|c|}{ Tekanan darah responden } & \multirow[b]{2}{*}{ Total } \\
\hline & Normal & Pre-hipertensi & Hipertensi & \\
\hline Laki-laki & 11 & 6 & 9 & 26 \\
\hline Perempuan & 7 & 2 & 4 & 13 \\
\hline Total & 18 & 8 & 13 & 39 \\
\hline
\end{tabular}

Tabel.3 Kejadian hipertensi berdasarkan kelompok umur

\begin{tabular}{|c|c|c|c|c|}
\hline \multirow[t]{2}{*}{ Kelompok umur } & \multicolumn{3}{|c|}{ Tekanan darah responden } & \multirow[b]{2}{*}{ Total } \\
\hline & Normal & Pre-hipertensi & Hipertensi & \\
\hline$<45$ tahun & 11 & 5 & 0 & 16 \\
\hline 45-60 tahun & 6 & 3 & 6 & 15 \\
\hline$>60$ tahun & 1 & 0 & 7 & 8 \\
\hline Total & 18 & 8 & 13 & 39 \\
\hline
\end{tabular}

Tabel 4. Kejadian Hipertensi berdasarkan konsumsi sayur

\begin{tabular}{lrrrrr}
\hline \multicolumn{1}{c}{$\begin{array}{c}\text { Konsumsi sayuran dalam } \\
\text { seminggu terakhir }\end{array}$} & \multicolumn{2}{c}{ Tekanan darah responden } & \\
\cline { 2 - 4 } & Normal & Pre-hipertensi & Hipertensi & Total \\
\hline Ya & 18 & 8 & 13 & 39 \\
\hline Tidak & 0 & 0 & 0 & 0 \\
\hline Total & $\mathbf{1 8}$ & $\mathbf{8}$ & $\mathbf{1 3}$ & $\mathbf{3 9}$ \\
\hline
\end{tabular}

Tabel 5. Kejadian hipertensi berdasarkan kecukupan konsumsi sayuran

\begin{tabular}{|c|c|c|c|c|}
\hline \multirow{2}{*}{$\begin{array}{c}\text { Kecukupan } \\
\text { Konsumsi sayuran }\end{array}$} & \multicolumn{3}{|c|}{ Tekanan darah responden } & \multirow[b]{2}{*}{ Total } \\
\hline & Normal & Pre-hipertensi & Hipertensi & \\
\hline Cukup & 4 & 2 & 0 & 6 \\
\hline Tidak Cukup & 14 & 6 & 13 & 33 \\
\hline Total & 18 & 8 & 13 & 39 \\
\hline
\end{tabular}


Proporsi Hipertensi Berdasarkan Kelompok Umur

Dari data yang diperoleh (tabel 3), kebanyakan penderita hipertensi adalah kelompok umur 60 tahun keatas sebesar $53.8 \%$, di mana dari 8 responden kelompok umur 60 tahun keatas, sebanyak 7 orang menderita hipertensi (87.5\%).

Proporsi Hipertensi Berdasarkan Konsumsi Sayuran Berdasarkan data, semua responden (tabel 4) mengkonsumsi sayuran di mana 13 dari 39 responden yang mengkonsumsi sayur (33.3\%) mengalami hipertensi. Berdasarkan kecukupan konsumsi sayuran, 6 responden (15.4\%) mengkonsumsi sayuran dalam kategori cukup di mana tidak ditemukan responden yang mengalami hipertensi. Dari 33 responden (84.6\%) yang mengkonsumsi sayuran dalam kategori tidak cukup, didapatkan 13 responden (39.4\%) mengalami hipertensi. Berdasarkan uji statistik Chi square untuk kecukupan konsumsi sayuran, didapatkan nilai $P$ sebesar 3.578 yang menunjukkan bahwa hasil penelitian ini tidak dapat digeneralisasi ke populasi dan hanya berlaku pada sampel.
Proporsi Hipertensi Berdasarkan Konsumsi Daging

Berdasarkan data (tabel 6), dari 39 responden sebanyak 38 responden (97.4\%) mengkonsumsi daging dan 1 responden (2.6\%) tidak mengkonsumsi daging. Dari 38 responden yang mengkonsumsi daging, sebanyak 12 responden (31.6\%) mengalami hipertensi dan dari 1 responden (2.6\%) yang tidak mengkonsumsi daging, sebanyak 1 responden (100\%) mengalami hipertensi. Dari 17 responden (44.7\%) yang mengkonsumsi daging merah, sebanyak 7 responden (41.2\%) mengalami hipertensi. Dari 14 responden $(36.8 \%)$ yang mengkonsumsi unggas, sebanyak 4 responden (28.6\%) mengalami hipertensi. Dari 7 responden (18.4\%) yang mengkonsumsi ikan, sebanyak 1 responden (14.3\%) mengalami hipertensi. Berdasarkan uji statistik Chi square untuk jenis daging yang dikonsumsi, didapatkan nilai $P$ sebesar 4.832 yang menunjukkan bahwa hasil penelitian ini tidak dapat digeneralisasi ke populasi dan hanya berlaku pada sampel.

Tabel 6. Kejadian Hipertensi berdasarkan konsumsi daging

\begin{tabular}{|c|c|c|c|c|}
\hline \multirow{2}{*}{$\begin{array}{l}\text { Konsumsi daging dalam } \\
\text { seminggu terakhir }\end{array}$} & \multicolumn{3}{|c|}{ Tekanan darah responden } & \multirow[b]{2}{*}{ Total } \\
\hline & Normal & Pre-hipertensi & Hipertensi & \\
\hline $\mathrm{Ya}$ & 18 & 8 & 12 & 38 \\
\hline Tidak & 0 & 0 & 1 & 1 \\
\hline Total & 18 & 8 & 13 & 39 \\
\hline
\end{tabular}

Tabel 7. Kejadian hipertensi berdasarkan jenis daging yang dikonsumsi

\begin{tabular}{|c|c|c|c|c|}
\hline \multirow{2}{*}{$\begin{array}{l}\text { Jenis daging } \\
\text { yang dimakan }\end{array}$} & \multicolumn{3}{|c|}{ Tekanan darah responden } & \multirow[b]{2}{*}{ Total } \\
\hline & Normal & Pre-hipertensi & Hipertensi & \\
\hline Daging merah & 6 & 4 & 7 & 17 \\
\hline Unggas & 7 & 3 & 4 & 14 \\
\hline Ikan & 5 & 1 & 1 & 7 \\
\hline Total & 18 & 8 & 12 & 38 \\
\hline
\end{tabular}

Tabel 8. Kejadian hipertensi berdasarkan jumlah potong daging yang dikonsumsi

\begin{tabular}{|c|c|c|c|c|}
\hline \multirow{2}{*}{$\begin{array}{l}\text { Jumlah potong daging yang } \\
\text { dikonsumsi dalam sehari }\end{array}$} & \multicolumn{3}{|c|}{ Tekanan darah responden } & \multirow[b]{2}{*}{ Total } \\
\hline & Normal & Pre-hipertensi & Hipertensi & \\
\hline$<2$ potong $(150 \mathrm{gr})$ & 11 & 0 & 6 & 17 \\
\hline $2-3$ potong (150 gr $-225 \mathrm{gr})$ & 6 & 7 & 6 & 19 \\
\hline$>3$ potong $(225 \mathrm{gr})$ & 1 & 1 & 0 & 2 \\
\hline Total & 18 & 8 & 12 & 38 \\
\hline
\end{tabular}

Berdasarkan data, dari 38 responden yang mengkonsumsi daging, sebanyak 17 responden (44.7\%) mengkonsumsi daging kurang dari 150 gr per hari, sebanyak 19 responden (50.0\%) mengkonsumsi daging 
antara $150 \mathrm{gr}$ hingga $225 \mathrm{gr}$ perhari dan sebanyak 2 responden (5.3\%) mengkonsumsi daging lebih dari 225 gr perhari. Dari 17 responden yang mengkonsumsi daging kurang dari 150 gr perhari, sebanyak 6 responden (35.3\%) mengalami hipertensi. Dari 19 responden yang mengkonsumsi daging antara 150 gr hingga 225 gram perhari, sebanyak 6 responden (31.6\%) mengalami hipertensi. Dari 2 responden yang mengkonsumsi daging lebih dari 225 grperhari, tidak terdapat responden yang mengalami hipertensi. Berdasarkan uji statistik Chi square untuk kebiasaan mengkonsumsi daging, didapatkan nilai $\mathrm{P}$ sebesar 2.053 yang menunjukkan bahwa hasil penelitian ini tidak dapat digeneralisasi ke populasi dan hanya berlaku pada sampel.

Tabel 9. Kejadian hipertensi berdasarkan konsumsi alkohol

\begin{tabular}{|c|c|c|c|c|}
\hline \multirow{2}{*}{$\begin{array}{l}\text { Konsumsi minuman beralkohol } \\
\text { dalam satu bulan terakhir }\end{array}$} & \multicolumn{3}{|c|}{ Tekanan darah responden } & \multirow[b]{2}{*}{ Total } \\
\hline & Normal & Pre-hipertensi & Hipertensi & \\
\hline Ya & 1 & 2 & 1 & 4 \\
\hline Tidak & 17 & 6 & 12 & 35 \\
\hline Total & 18 & 8 & 13 & 39 \\
\hline
\end{tabular}

Proporsi Hipertensi Berdasarkan Konsumsi Alkohol Berdasarkan data (tabel 9), dari 39 responden didapatkan sebanyak 4 responden (10.2\%) mengkonsumsi minuman beralkohol dengan kadar alkohol 1\%-5\% dan frekuensi kurang dari 5 hari per minggu. Sebanyak 35 responden (89.7\%) tidak mengkonsumsi minuman beralkohol. Dari 4 responden yang mengkonsumsi minuman beralkohol, sebanyak 1 responden (25\%) mengalami hipertensi dan dari 35 responden yang tidak mengkonsumsi minuman beralkohol, sebanyak 12 responden (34.3\%) mengalami hipertensi. Berdasarkan uji statistik Chi square untuk kebiasaan minum minuman beralkohol, didapatkan nilai $\mathrm{P}$ sebesar 2.414 yang menunjukkan bahwa hasil penelitian ini tidak dapat digeneralisasi ke populasi dan hanya berlaku pada sampel.

Proporsi Hipertensi Berdasarkan Kebiasaan Melakukan Aktivitas Fisik
Berdasarkan data (tabel 10), dari 39 responden sebanyak 18 responden (46.2\%) melakukan aktivitas fisik dan sebanyak 21 responden (53.8\%) tidak melakukan aktivitas fisik. Dari 18 responden yang melakukan aktivitas fisik, sebanyak 4 responden (22.2\%) mengalami hipertensi dan dari 21 responden yang tidak melakukan aktivitas fisik, sebanyak 9 responden (42.9\%) mengalami hipertensi. Dari 18 responden yang melakukan aktivitas fisik, sebanyak 10 responden (55.6\%) termasuk dalam kategori kurang dalam melakukan aktivitas fisik di mana sebanyak 1 responden (10.0\%) mengalami hipertensi. Sebanyak 8 responden (44.4\%) termasuk dalam kategori cukup dalam melakukan aktivitas fisik di mana sebanyak 3 responden (37.5\%) mengalami hipertensi. Berdasarkan uji statistik Chi square untuk kebiasaan melakukan aktivitas fisik, didapatkan nilai $P$ sebesar 1.926 yang menunjukkan bahwa hasil penelitian ini tidak dapat digeneralisasi ke populasi dan hanya berlaku pada sampel.

Tabel 10. Kejadian hipertensi berdasarkan kebiasaan melakukan aktivitas fisik

\begin{tabular}{|c|c|c|c|c|}
\hline \multirow{2}{*}{$\begin{array}{l}\text { Aktivitas fisik dalam satu } \\
\text { minggu terakhir }\end{array}$} & \multicolumn{3}{|c|}{ Tekanan darah responden } & \multirow[b]{2}{*}{ Total } \\
\hline & Normal & Pre-hipertensi & Hipertensi & \\
\hline $\mathrm{Ya}$ & 10 & 4 & 4 & 18 \\
\hline Tidak & 8 & 4 & 9 & 21 \\
\hline Total & 18 & 8 & 13 & 39 \\
\hline
\end{tabular}

Tabel 11. Kejadian hipertensi berdasarkan total waktu melakukan aktivitas fisik

\begin{tabular}{|c|c|c|c|c|}
\hline \multirow{2}{*}{$\begin{array}{l}\text { Total waktu melakukan aktivitas fisik } \\
\text { dalam satu minggu }\end{array}$} & \multicolumn{3}{|c|}{ Tekanan darah responden } & \multirow[b]{2}{*}{ Total } \\
\hline & Normal & Pre-hipertensi & Hipertensi & \\
\hline $\begin{array}{l}<150 \text { menit/minggu } \\
\text { (kurang melakukan aktivitas fisik) }\end{array}$ & 7 & 2 & 1 & 10 \\
\hline $\begin{array}{l}\geq 150 \text { menit/minggu } \\
\text { (cukup melakukan aktivitas fisik) }\end{array}$ & 3 & 2 & 3 & 8 \\
\hline
\end{tabular}




\section{Total}

\section{PEMBAHASAN}

Dari hasil penelitian di atas, didapatkan bahawa prevalensi hipertensi pada sampel sebesar 13 penderita yang mengalami hipertensi dari 39 sampel atau 33.3\%. Di mana kebanyakan penderita hipertensi adalah lakilaki sebesar $69.2 \%$, sedangkan perempuan sebesar $30.8 \%$. Mayoritas penderita hipertensi adalah kelompok umur diatas 60 tahun sebesar $53.8 \%$.

Dari 39 sampel, 30 responden (76.9\%) mengkonsumsi buah-buahan dan 9 responden (23.1\%) tidak mengkonsumsi buah-buahan. Di mana dari 30 responden yang mengkonsumsi buah, 10 responden (33.3\%) mengalami hipertensi dan dari 9 responden yang tidak mengkonsumsi buah, 3 responden (33.3\%) mengalami hipertensi. Berdasarkan kecukupan konsumsi buah, sebanyak 1 responden (33.3\%) mengkonsumsi buah dalam kategori cukup dan 29 responden (96.7\%) mengkonsumsi buah dalam kategori tidak cukup. Dari 29 responden yang mengkonsumsi buah dalam kategori tidak cukup, sebanyak 10 responden (34.5\%) mengalami hipertensi dan dari responden yang mengkonsumsi buah dalam kategori cukup, tidak ditemukan responden yang mengalami hipertensi.

Dari 39 sampel, semua responden mengkonsumsi sayuran di mana 13 dari 39 responden yang mengkonsumsi sayur (33.3\%) mengalami hipertensi. Berdasarkan kecukupan konsumsi sayuran, 6 responden (15.4\%) mengkonsumsi sayuran dalam kategori cukup di mana tidak ditemukan responden yang mengalami hipertensi. Dari 33 responden (84.6\%) yang mengkonsumsi sayuran dalam kategori tidak cukup, didapatkan 13 responden (39.4\%) mengalami hipertensi. Sebanyak 38 responden (97.4\%) mengkonsumsi daging dan 1 responden (2.6\%) tidak mengkonsumsi daging. Dari 38 responden yang mengkonsumsi daging, sebanyak 12 responden (31.6\%) mengalami hipertensi dan dari 1 responden (2.6\%) yang tidak mengkonsumsi daging, sebanyak 1 responden (100\%) mengalami hipertensi. Dari 38 responden yang mengkonsumsi daging, sebanyak 17 responden (44.7\%) mengkonsumsi daging kurang dari $150 \mathrm{gr}$ per hari, sebanyak 19 responden (50.0\%) mengkonsumsi daging antara $150 \mathrm{gr}$ hingga 225 gr perhari dan sebanyak 2 responden (5.3\%) mengkonsumsi daging lebih dari 225 gr perhari. Dari 17 responden yang mengkonsumsi daging kurang dari 150 gr perhari, sebanyak 6 responden (35.3\%) mengalami hipertensi. Dari 19 responden yang mengkonsumsi daging antara $150 \mathrm{gr}$ hingga 225 gr perhari, sebanyak 6 responden (31.6\%) mengalami hipertensi. Dari 2 responden yang mengkonsumsi daging lebih dari $225 \mathrm{gr}$ perhari, tidak terdapat responden yang mengalami hipertensi.

\section{0} 4

Dari 39 sampel, didapatkan 13 responden (33.3\%) merokok dan 26 responden (66.7\%) tidak merokok. Dari 13 responden yang merokok, sebanyak 2 responden (15.4\%) mengalami hipertensi dan dari 26 responden yang tidak merokok, sebanyak 11 responden (42.3\%) mengalami hipertensi. Dari semua responden yang merokok, sebanyak 6 responden (46.2\%) termasuk kategori perokok ringan di mana sebanyak 2 responden (33.3\%) mengalami hipertensi. Sebanyak 7 responden (53.8\%) termasuk kategori perokok sedang di mana tidak ditemukan responden yang mengalami hipertensi. Tidak ditemukan responden dalam kategori perokok berat.

Dari 39 sampel, didapatkan sebanyak 4 responden (10.2\%) mengkonsumsi minuman beralkohol dengan kadar alkohol 1\%-5\% dan frekuensi kurang dari 5 hari per minggu. Sebanyak 35 responden (89.7\%) tidak mengkonsumsi minuman beralkohol. Dari 4 responden yang mengkonsumsi minuman beralkohol, sebanyak 1 responden (25\%) mengalami hipertensi dan dari 35 responden yang tidak mengkonsumsi minuman beralkohol, sebanyak 12 responden (34.3\%) mengalami hipertensi.

Dari 39 sampel, sebanyak 18 responden (46.2\%) melakukan aktivitas fisik dan sebanyak 21 responden (53.8\%) tidak melakukan aktivitas fisik. Dari 18 responden yang melakukan aktivitas fisik, sebanyak 4 responden (22.2\%) mengalami hipertensi dan dari 21 responden yang tidak melakukan aktivitas fisik, sebanyak 9 responden (42.9\%) mengalami hipertensi. Dari 18 responden yang melakukan aktivitas fisik, sebanyak 10 responden (55.6\%) termasuk dalam kategori kurang dalam melakukan aktivitas fisik di mana sebanyak 1 responden (10.0\%) mengalami hipertensi. Sebanyak 8 responden (44.4\%) termasuk dalam kategori cukup dalam melakukan aktivitas fisik di mana sebanyak 3 responden (37.5\%) mengalami hipertensi.

Kelemahan Penelitian

- Informasi yang diperoleh hanya didasarkan wawancara dan pengakuan dari responden, tanpa adanya observasi. Sehingga kita tidak mengetahui apakah jawaban yang dikatakan oleh responden adalah benar atau tidak saat dilakukan wawancara.

- Sampel yang diperoleh untuk melihat kecenderungan hipertensi terhadap gaya hidup tidak dapat digeneralisasi ke populasi dan hanya berlaku pada sampel.

\section{PENUTUP}

Simpulan 
1. Berdasarkan penelitian yang telah dilakukan dapat ditarik simpulan bahwa prevalensi hipertensi pada sampel sebesar 13 penderita dari 39 sampel atau 33.3\% di mana kejadian hipertensi paling banyak terjadi pada kelompok umur diatas 60 tahun sebesar $53.8 \%$ dan mayoritas terjadi pada laki-laki yaitu $69.2 \%$.

2. Berdasarkan data yang dikumpulkan, dari 39 responden sebanyak 30 responden mengkonsumsi buah dimana ditemukan 10 responden (33.3\%) mengalami hipertensi dan 9 responden tidak mengkonsumsi buah dimana ditemukan 3 responden (33.3\%) mengalami hipertensi. Dari 30 responden yang mengkonsumsi buah, sebanyak 1 responden (33.3\%) mengkonsumsi buah dalam kategori cukup dimana tidak ditemukan responden yang mengalami hipertensi dan 29 responden $(96.7 \%)$ mengkonsumsi buah dalam kategori tidak cukup dimana sebanyak 10 responden (34.5\%) mengalami hipertensi. Semua responden mengkonsumsi sayuran di mana 13 dari 39 responden yang mengkonsumsi sayur (33.3\%) mengalami hipertensi. Berdasarkan kecukupan konsumsi sayuran, 6 responden (15.4\%) mengkonsumsi sayuran dalam kategori cukup di mana tidak ditemukan responden yang mengalami hipertensi dan 33 responden (84.6\%) mengkonsumsi sayuran dalam kategori tidak cukup, dimana didapatkan 13 responden (39.4\%) mengalami hipertensi. Sebanyak 38 responden (97.4\%) mengkonsumsi daging dan 1 responden $(2.6 \%)$ tidak mengkonsumsi daging. Dari 38 responden yang mengkonsumsi daging, 12 responden (31.6\%) mengalami hipertensi dan dari 1 responden (2.6\%) yang tidak mengkonsumsi daging, 1 responden (100\%) mengalami hipertensi. Dari semua responden yang mengkonsumsi daging, 17 responden (44.7\%) mengkonsumsi daging merah dimana sebanyak 7 responden (41.2\%) mengalami hipertensi, 14 responden (36.8\%) mengkonsumsi unggas dimana sebanyak 4 responden (28.6\%) mengalami hipertensi dan 7 responden (18.4\%) mengkonsumsi ikan dimana sebanyak 1 responden (14.3\%) mengalami hipertensi. Dari seluruh responden, 13 responden (33.3\%) merokok dan 26 responden (66.7\%) tidak merokok. Dimana dari 13 responden yang merokok sebanyak 2 responden (15.4\%) mengalami hipertensi dan dari 26 responden yang tidak merokok sebanyak 11 responden (42.3\%) mengalami hipertensi. 4 responden mengkonsumsi minuman beralkohol dimana sebanyak 1 responden (25\%) mengalami hipertensi, dan 35 responden tidak mengkonsumsi minuman beralkohol dimana sebanyak 12 responden (34.3\%) mengalami hipertensi. Sebanyak 18 responden (46.2\%) melakukan aktivitas fisik dan sebanyak 21 responden (53.8\%) tidak melakukan aktivitas fisik. Dari 18 responden yang melakukan aktivitas fisik, sebanyak 4 responden (22.2\%) mengalami hipertensi dan dari 21 responden yang tidak melakukan aktivitas fisik, sebanyak 9 responden (42.9\%) mengalami hipertensi

3. Dari uji statistik yang sudah dilakukan, didapatkan hasil Chi square tidak dapat digeneralisasi ke populasi dan hanya berlaku pada sampel. Namun peneliti melihat adanya kecenderungan peningkatan tekanan darah terhadap konsumsi buah dan sayuran dengan kecukupan yang kurang, konsumsi daging terutama jenis daging merah, serta kurangnya melakukan aktivitas fisik.

$\underline{\text { Saran }}$

1. Sebagai masukan kepada puskesmas untuk mengadakan promosi kesehatan di Desa Menanga oleh karena berdasarkan penelitian, ditemukan adanya kecenderungan hipertensi berdasarkan gaya hidup.

2. Diharapkan pihak puskesmas dapat memberikan perhatian lebih untuk memberikan informasi kepada masyarakat baik berupa upaya promotif maupun preventif terhadap faktor-faktor risiko yang berpengaruh terhadap angka kejadian hipertensi terutama kebiasaan konsumsi buah dan sayuran yang kurang, kebiasaan konsumsi daging, dan aktivitas fisik yang kurang.

3. Pihak puskesmas diharapkan melaksanakan pemeriksaan tekanan darah secara rutin kepada masyarakat setempat yang bertujuan untuk mendeteksi dan memulai pengobatan terhadap hipertensi sedini

\section{DAFTAR PUSTAKA}

1. Mansjoer Arief. Nefrologi dan hipertensi. Dalam: Kapita selekta, edisi 3. Jakarta: Media Aesculapius FK-UI.2001. hal. 518-522.

2. Kearney P. Worldwide prevalence of hypertension: $\quad a \quad$ systematic review.2004.Available at: http://www.PubMed.com(Accessed: June 15, 2011)

3. Amalia, Husnul. Hipertensi Dan Faktor risikonya Dalam Kajian Epidemiologi.2007.Available : 
http://ridwanamiruddin.wordpress.com

(Accessed: June 15, 2011)

4. Departemen Kesehatan Ri. Laporan Riskesdas 2007 Provinsi Bali. Jakarta: Badan Penelitian dan Pengembangan Kesehatan.2008.

5. Ekowati Rahajeng. Masalah Hipertensi Di Indonesial.2009.Available at: gdladm@lubang.depkes.go.id (Accessed: June 15, 2011).

6. J Ayub Med Coll Abbottabad. Frequency of Hypertension in Stroke Patients Presenting at Ayub Teaching Hospital. J Ayub Med Coll Abbottabad 2006;18(1).

7. Anonim. Faktor Resiko Hipertensi Yang Tidak Dapat Dikontrol,2011.Available at: http://www.klikbatam.com (Accessed: June 16, 2011)

8. Anonim. Faktor Resiko Hipertensi Yang Dapat Dikontrol,2011.Available at:

http://www.smallcrab.com/kesehatan/511faktor-resiko-hipertensi-yang-dapat-dikontrol (Accessed: June 16, 2011)

9. RiazK. Hypertension,2011. Available at: http://emedicine.medscape.com/article/24138 1-overview (Accessed: June 16, 2011)

10. Gauri Waikar. Fruits, Vegetables that Lower Blood Pressure,2009. Available at: http://www.buzzle.com/fruitsandvegetablestha tlowerbloodpressuce (Accessed: June 15, 2011).

11. Madhura P. Effects of Alcohol on Blood Pressure,2009. Available at: http://www.buzzle.com/effectsofalcoholonbloo dpressure (Accessed: June 15, 2011) 